\title{
Vertical diel dynamic of fish assemblage associated with an artificial reef (Northern Adriatic Sea)
}

\author{
ANTONELLO SALA, GIANNA FABI and SARINE MANOUKIAN \\ National Research Council, Institute of Marine Sciences, Marine Fisheries Section (CNR-ISMAR), Largo Fiera della \\ Pesca, 60125 Ancona, Italy.E-mail: a.sala@ismar.cnr.it
}

\begin{abstract}
SUMMARY: The vertical diel activity of a fish assemblage inhabiting the Senigallia artificial reef (northern Adriatic Sea, Italy) was evaluated from July to November 1996 using enhanced hydroacoustic techniques. Extensive seabed mapping of the area was done using a multibeam echosounder to obtain background imagery of the reef structures and identify the most suitable locations for placing stationary acoustic transducers. Three acoustic transducers were placed inside the reef area, while a fourth was located in the open sea outside the area. Data analysis was conducted on three different depth layers: surface, midwater and bottom. In each layer, diel fish biomass inside the reef showed two peaks, one in the early morning and the other in the late evening. Slightly different behaviour was observed outside the protected area. Comparison of the layers showed that fish biomass was not homogeneously distributed along the water column throughout the sampling period. There were high values in the middle and bottom layers until the end of August. However, no significant biomass variations in time were observed outside the reef where low values were always recorded in each layer.
\end{abstract}

Keywords: Adriatic Sea, artificial reef, fish biomass, multibeam sonar, split-beam hydroacoustic.

RESUMEN: DiNÁMICA DIARIA VERTICAL DE COMUNIDADES DE PECES ASOCIADOS A UN ARRECIFE ARTIFICIAL (MAR AdRIÁTICO NORTE). - La actividad diaria vertical de la comunidad de peces que habitan en el arrecife artificial Senigallia (Mar Adriatico Norte, Italia), se evaluó desde julio a noviembre de 1996 utilizando técnicas de hidroacústica. Se realizó un mapaje extenso del fondo marino utilizando una ecosonda multihaz para obtener imágenes de las estructuras del arrecife e identificar las áreas más adecuadas para emplazar los transductores acústicos. Tres fueron colocados dentro del área del arrecife, mientras que un cuarto fue situado en mar abierto, fuera del área. El análisis de datos se realizó a tres profundidades: superficie, profundidad intermedia y fondo. En cada profundidad la biomasa diaria de peces en el arrecife mostraba dos picos, uno por la mañana y otro al anochecer. Pequeñas diferencias en el comportamiento de los peces se observaron fuera del área protegida. Comparando entre las distintas profundidades mostramos que la biomasa de los peces no estaba uniformemente distribuida a lo largo de la columna de agua, durante el período de muestreo, con valores altos en las profundidades intermedias $\mathrm{y}$ en el fondo hasta finales de agosto. Por otro lado no se observaron variaciones de biomasa significativas en el tiempo fuera del arrecife donde siempre prevalecieron valores bajos en cada profundidad.

Palabras clave: mar Adriático, arrecife artificial, sonar multihaz, hidoacústica.

\section{INTRODUCTION}

Information about fish assemblages occurring around artificial reefs, such as species composition, diel and seasonal movements, as well as relationships with the artificial substrates, is essential for assessing the role that an artificial habitat can play on an original fish community.
A visual census carried out by scuba divers or using a remotely operated vehicle (ROV) is the most frequently used method for assessing the fish assemblage on natural rocky bottoms and at artificial reefs (Bortone and Kimmel, 1991; Okamoto, 1991; Charbonnel et al., 1997). Advantages of using this non-destructive technique include its adaptability to a wide range of conditions and the possibility 
of putting the observer in direct contact with the organisms and habitats being surveyed, thereby allowing a considerable amount of useful information to be gathered. The disadvantages are depth constraints, the influence of visual conditions, avoidance, and the variability of behavioural patterns of the different species. Poor visibility may result either from a lack of light at night, on overcast days and in deep waters, or water turbidity due to suspended sediments, mixing of water masses with different salinities, and high plankton concentrations (Bortone and Mille, 1999). Demartini et al. (1989) noted that sampling may be drastically affected when the water transparency is less than $3 \mathrm{~m}$. In addition, the spatial heterogeneity of the artificial modules and the behaviour of cryptic species may reduce the probability of a specimen being found. This leads to the actual population being underestimated (Wickham and Russel, 1974; Buckley and Hueckel, 1985; Harmelin-Vivien et al., 1985). Nonvisual techniques consist of fishing sampling with relatively non-destructive gear (hook-and-lines, set nets, traps). An advantage of using capture methods is that they provide specimens for gathering life-history data not obtainable from living organisms, such as sex and reproductive condition, age, and feeding habits. Another advantage is that these techniques are also effective at night and, when associated with diurnal sampling, can give a picture of the entire reef assemblage. Nevertheless, these results can also be affected by several factors, such as the behaviour of the different species, the difficulty of setting the gear close to structures, impacts of removals and the selectivity of the gear being used (Miller and Hunte, 1987; Somerton et al., 1988; Bombace et al., 1997).

The most recent advancement involves using stationary hydroacoustic technology to study fish abundance, distribution, and behaviour in specific areas. This method has been successfully employed in surveying fish assemblages at hydroelectric facilities in riverine environments and around oil and gas platforms (Thorne et al., 1990; Thorne, 1994; Stanley et al., 1994; Stanley and Wilson, 1998; Soldal et al., 2002); however, thus far applying this technique to artificial reefs has been very limited (Thorne et al., 1989). The advantages are that, if strategically placed, the transducer arrays can provide the necessary spatial coverage. They can "see" along the entire water column or at specific depths and when combined with computerised data records, long-term, time-series data can be collected. The main disadvantage is the difficulty of identifying the species, especially in a multi-species assemblage like that which typically inhabits an artificial reef.

An aspect that is commonly ignored when assessing the fish assemblage at an artificial reef is the current state of the structures. Studies usually refer to the initial arrangement of the artificial substrates but do not take into account movements and alterations that may occur over time. It is unfortunate that this data is missing because having a detailed picture of the artificial reef arrangement and the placement of the single units at the time of the fish assessment is indispensable. The arrangement, distance, shape and dimensions of modules can strongly affect the composition and behaviour of the reef fish assemblage based on the reefiness of the different species (Nakamura, 1985; Bombace, 1989; Okamoto, 1991). Relief imagery produced from multibeam bathymetric data provides valuable and detailed base maps for seafloor investigation and interpretation (Todd et al., 1999; Mosher and Thomson, 2002). These maps help define the geological variability of the seafloor and improve the understanding of the processes that control the distribution and transport of bottom sediments, as well as the distribution of benthic habitats and associated infaunal community structures (Popper et al., 2006). Although shallow-water multibeam sonar technology (MBES) has been largely employed in mapping seabed morphology and composition (Augustin et al., 1996; Cauwenberghe, 1996; Mitchell, 1996; Shaw et al., 1997; Kammerer et al., 1998; Acosta et al., 2001; Dziak et al., 2001; Beyer et al., 2005; Knaapen et al., 2005; Chakraborty et al., 2006; Mayer, 2006), pipeline routes (Hansen and Simonis, 1994; Clasper, 1996; Paton et al., 1997; Ross et al., 2004), coral reefs (Grigg et al., 2002; Hovland et al., 2002; Conway et al., 2005; Roberts et al., 2005), and searching wrecks (Singh et al., 2000; Lawrence et al., 2001; Mayer and Kenneth, 2001; Mayer et al., 2003), it has not been used often in the fine detection of reef units, or to investigate their horizontal and vertical movements and subsidence (Shyue, 1998; Shyue and Yang, 2002).

Starting with the above considerations, we carried out an assessment study at a 9-year old artificial reef deployed in the northern Adriatic Sea using an acoustic method involving both multibeam sonar for artificial reef mapping and a scientific echosounder for analysing fish distribution and movements during diel cycles at different periods of the year. The 
aim was to investigate the distribution of the reef fish assemblage in relation to the arrangement and state of the structures. The present paper refers to the diel variations of the fish biomass along the water column recorded over a 4-month period.

\section{MATERIALS AND METHODS}

The study was carried out at the Senigallia artificial reef, located approximately $15 \mathrm{~nm} \mathrm{NW}$ from Ancona. It was built-up in 1987 about $1.2 \mathrm{~nm}$ offshore on a sandy-mud seabed far from natural hard substrates, at a mean depth of $12.5 \mathrm{~m}$ (Fig. 1). The reef consists of 29 pyramids, each made of five $2 \mathrm{~m}$ cubic concrete blocks and twelve concrete cages $(6 \times 4 \times 5 \mathrm{~m})$ for shellfish culture, placed in a rectangular arrangement (Fabi and Fiorentini, 1994). It has a warning light placed on a fixed pile rising about $5 \mathrm{~m}$ above the sea surface. The water temperature ranges from $7^{\circ} \mathrm{C}$ in winter to $26-27^{\circ} \mathrm{C}$ in summer, without a significant difference between surface and bottom. Poor underwater visibility is very common due to fluvial input and sediment suspension agitated by storms. This makes it difficult to carry out regular visual observations over an extended period. For this reason the evolution of the fish population around the reef was surveyed using a bottom trammel net (Bombace et al., 1997; 2000; Fabi et al., 1999a).

In order to investigate the state of the structures after about 9 years from their deployment a Simrad EM3000 bathymetric system mounted on the CNRISMAR (Ancona) R/V “Tecnopesca II" was used to map the reef. The sonar operated at a frequency of $300 \mathrm{kHz}$, fanning out up to 127 acoustic beams at a maximum ping rate of $25 \mathrm{~Hz}$ and an angle of $140^{\circ}$ $\left(1.5^{\circ} \times 1.5^{\circ}\right.$ beams are spaced $0.9^{\circ}$ apart $)$. This yielded swaths that were up to $\sim 4$ times the water depth. The position of the boat was obtained via a 24-hour, differential global positioning system (DGPS) navigation connected to a geostationary satellite, an Anshutz Standard 20 gyrocompass, and a sound velocimeter. With differential GPS, the system was capable of $\mathrm{cm}$ resolution with a depth accuracy of 10 to $15 \mathrm{~cm}$ RMS and a horizontal positional accuracy of less than $1 \mathrm{~m}$. The data were logged using Simrad Merlin software, edited for spurious bathymetric and navigational values, and subsequently processed using CARIS software. Tidal cor-

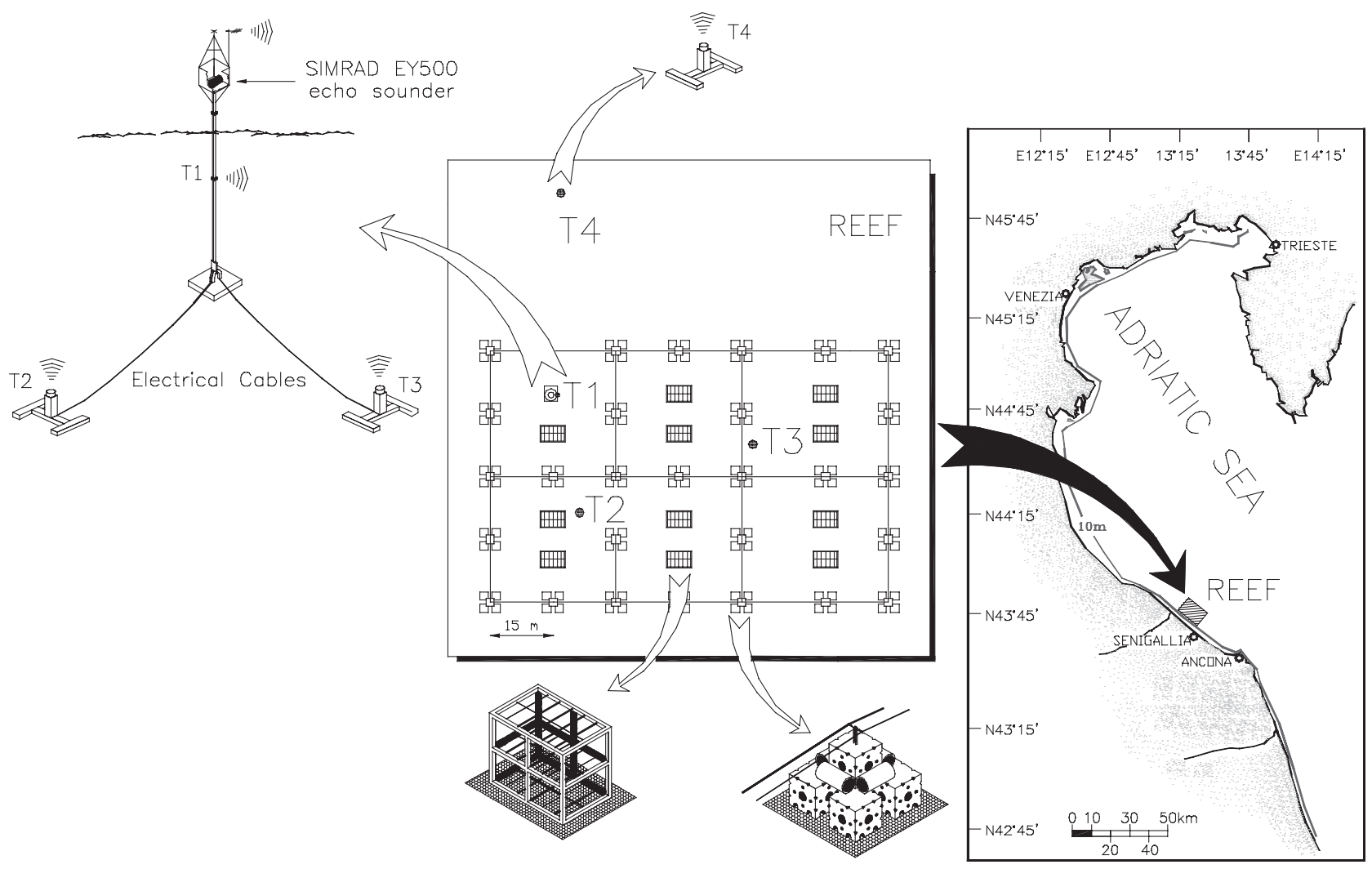

FIG. 1. - Location and schematic plan of the Senigallia (Ancona, Italy) artificial reef. 


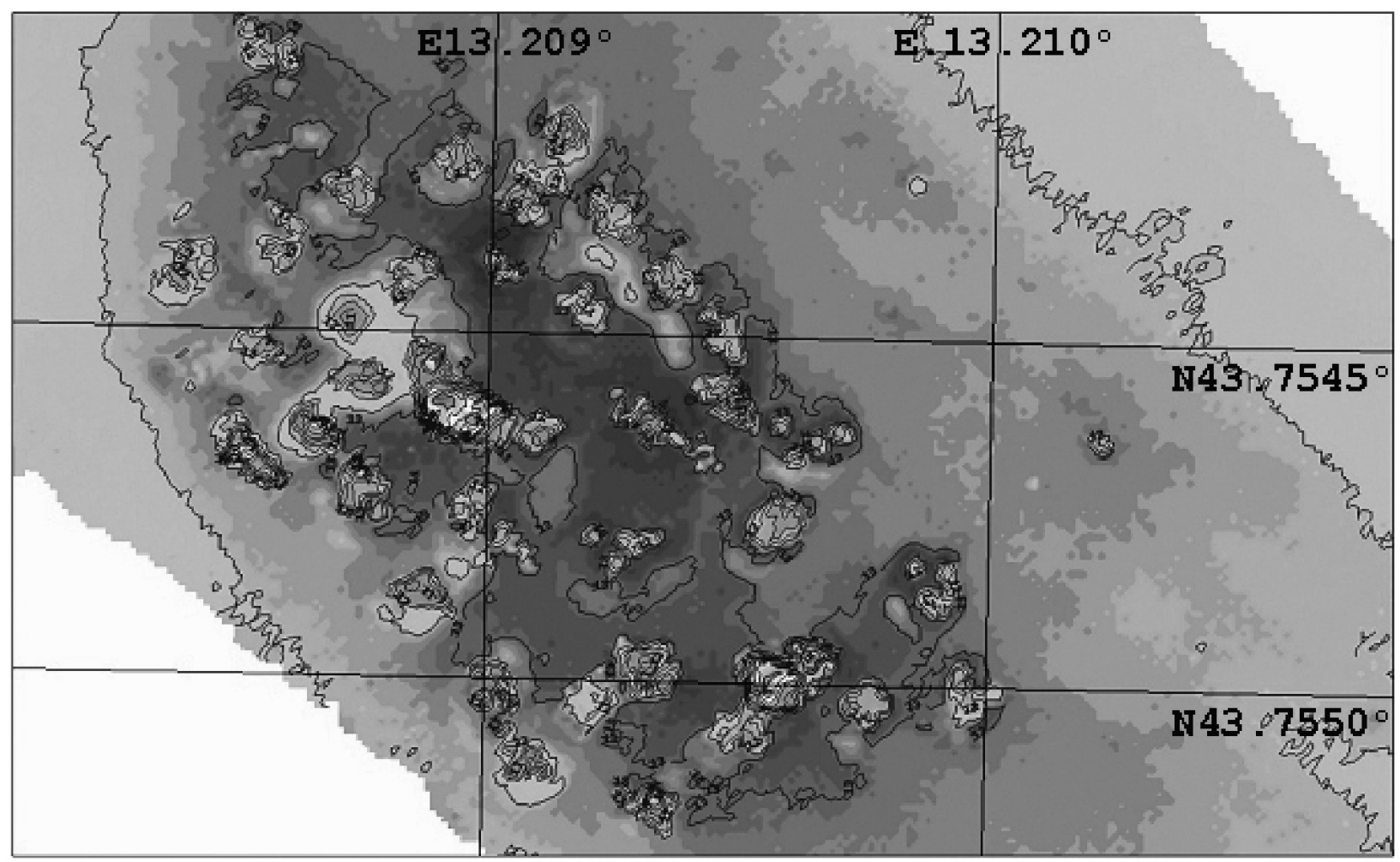

Mean depth [m]

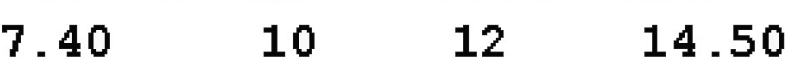

FIG. 2. - Bathymetric map of the Senigallia artificial reef, created from Kongsberg-Simrad EM-3000 data. Map projection is Mercator.

rections were applied to the depth soundings by using verified downloaded tide data available for the study area from the National Hydrographic and Mareographic Institute of Rome. The gridded data were exported as ASCII files and imported into CFloor software for processing and image production. Therefore, not only bathymetric charts could be created, but also Digital Terrain Models and 3D block diagrams of the surveyed area.

To assess the vertical diel dynamics of the fish assemblage, a modified Simrad EY500 hydroacoustic system was used. The modified system consisted of a transceiver, a laptop, a power supply (four electric batteries: 12V-100Ah, charged with solar panels), a transducer multiplexing (Simrad MP500), a timer to periodically power the system and four ES120 split-beam transducers (operating frequency $120 \mathrm{kHz}$, beam angle $7.1^{\circ}$ ). All the equipment, with the exception of the ES120 split-beam transducers, was packed inside a waterproof case on the fixed pile placed within the reef area. The field system was linked by a radio-modem (VTX 4800 baud) to a personal computer installed in the Institute, which automatically controlled data acquisition and provided the correct functioning of the EY500 system in real time.

In accordance with previous studies (Stanley and Wilson, 1998), the system was started by the timer for 16 min every $2 \mathrm{~h}$, encompassing four periods (dawn, noon, dusk and midnight) over a $24 \mathrm{~h}$ interval. Based on the maps of the reef obtained from MBES investigation (Figs. 2 and 3), the four transducers were set to measure in situ fish target strength distribution and density. Transducer 1 (T1), placed $4 \mathrm{~m}$ deep on the pile of the fixed light signal was horizontally oriented towards the centre of the reef. Transducers 2 and 3 (T2, T3) were located on steel frames placed on the seabed inside the reef and oriented upwards: the former was placed in a zone with high concentration of substrates, the latter in a wide space among the pyramids. Finally, transducer 4 (T4) was oriented towards the surface, in the same way as $\mathrm{T} 2$ and $\mathrm{T} 3$, but located on the seabed outside the reef, at about $80 \mathrm{~m}$ distance (Fig. 3). Transducers 


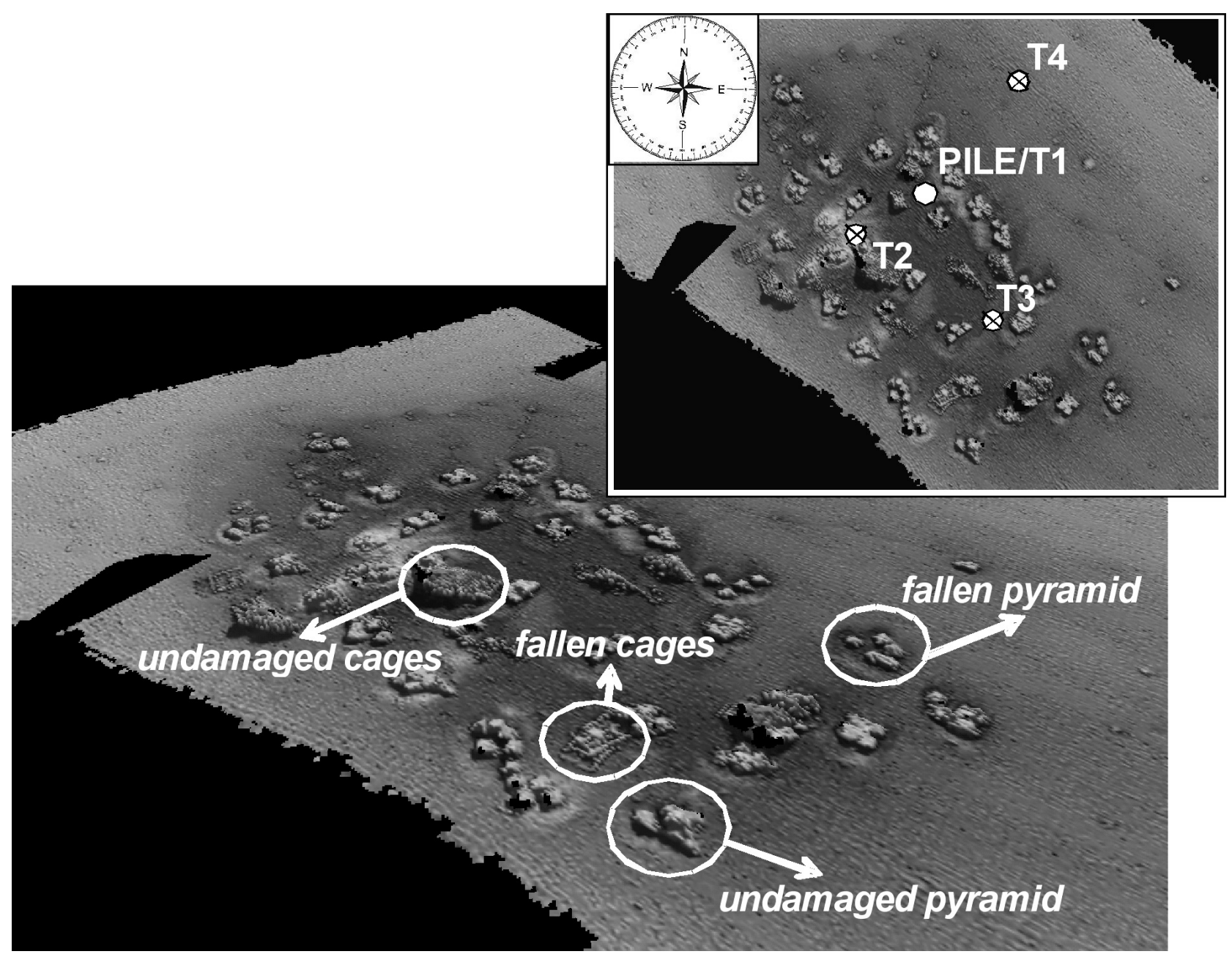

FIG. 3. - Gray-scale, sun-illuminated, three-dimensional perspective map of the Senigallia artificial reef, produced from multibeam bathymetric data. It is possible to observe the pyramids (fallen and undamaged) in their sound structure of fine $2 \mathrm{~m}$ cubic concrete blocks, and the cages (fallen and undamaged). The small boxing shows the placement of the four transducers.

$\mathrm{T} 2, \mathrm{~T} 3$ and $\mathrm{T} 4$ were placed at depths ranging from 12.35 to $13.00 \mathrm{~m}$.

The three transducers (T1, T2 and T3) located inside the reef began to collect data from 21 July 1996, while the fourth (T4) started on 2 August 1996 (Table 1). The system collected data until 14 November of the same year. The entire period was subdivided into eight intervals, each with a duration

TABLE 1. - Hydroacoustic sampling intervals.

\begin{tabular}{lcc}
\hline Sampling interval & Start & End \\
\hline S1 & & \\
S2 & 21 Jul 96 & 30 Jul 96 \\
S3 & 02 Aug 96 & 08 Aug 96 \\
S4 & 11 Aug 96 & 17 Aug 96 \\
S5 & 20 Aug 96 & 29 Aug 96 \\
S6 & 02 Sep 96 & 09 Sep 96 \\
S7 & 25 Sep 96 & 30 Sep 96 \\
S8 & 02 Oct 96 & 12 Oct 96 \\
& 01 Nov 96 & 14 Nov 96 \\
\hline
\end{tabular}

of approximately eight days (Table 1) depending on battery life. The data recorded by the horizontallyaligned transducer (T1) were not examined in this paper because it only explored a distinct layer $(4 \mathrm{~m}$ deep) of the water column. A more detailed description of the survey methodology is given by Fabi and Sala (2002).

The acoustic raw data recorded by the vertically oriented transducers (T2, T3 and T4) were postprocessed with the Simrad EP500 software (Ver. 5.0) and stored in a database. For each transducer, data were extracted from the database into tables with acoustic area backscattering values $\left(S_{a}\right)$ for each 3-m depth interval from the surface to the bottom, which generated three different depth layers: surface, midwater and bottom layer. All $\mathrm{S}_{\mathrm{a}}$ data were subsequently grouped into hourly values by generating the means of $S_{a}$ by depth stratum recorded within 2 hours. $S_{a}$ values were used to calculate the mean 
fish biomass at each hour of the day and each sampling period. The data recorded by the fixed acoustic transducers are presented as a mean vertical dynamic of fish biomass recorded in the water column by the vertically-aligned transducers both on diel interval and during the overall sampling period.

Mean fish biomass obtained with T2, T3 and T4 in the different sampling intervals was compared using a three-way variance analysis (Snedecor and Cochran, 1967). The factors were transducer, depth layer and interval. Tukey's HSD test was used to make comparisons across all pairs of group means when corresponding ANOVA tests were significant $(\mathrm{P}<0.05)$. Prior to performing ANOVA tests, the normality (Kolmogorov-Smirnov test) and homogeneity of variances (Levene's test) of the data were verified. When these assumptions were not verified, a $\ln (x+1)$ transformation was applied to all data.

\section{RESULTS}

The complete bathymetric coverage of the Senigallia survey area showed that the depth inside the reef ranged from 12.35 to $13.45 \mathrm{~m}$. Therefore, it was slightly deeper and less homogeneous with respect to the surrounding open-sea bottom (Fig. 2). Moreover, the 3D map evidenced that several pyramids had collapsed and the cubic blocks had spread out, in some cases forming a continuous system, while a few of them were partially sunken into the sandy-mud seabed reaching a height of only 1.5-2.0 $\mathrm{m}$ above the bottom. A few concrete cages had also fallen and lay on the seabed partially covered by the sediment (Fig. 3).

Figure 4 shows the isopleth diagrams of the mean vertical diel dynamic of fish biomass recorded along the water column by transducers T2, T3 and $\mathrm{T} 4$. The most consistent feature was a regular diel pattern of the mean fish biomass inside the reef (T2, T3) which generally appeared to be negatively correlated with light intensity, peaking at late evening and in the early morning. The depth of the highest fish biomass values varied between the two transducers: in the area explored by $\mathrm{T} 2$ the highest biomasses were consistently recorded in the bottom and midwater layers, while in the T3 area the early morning peak occurred in the midwater and surface

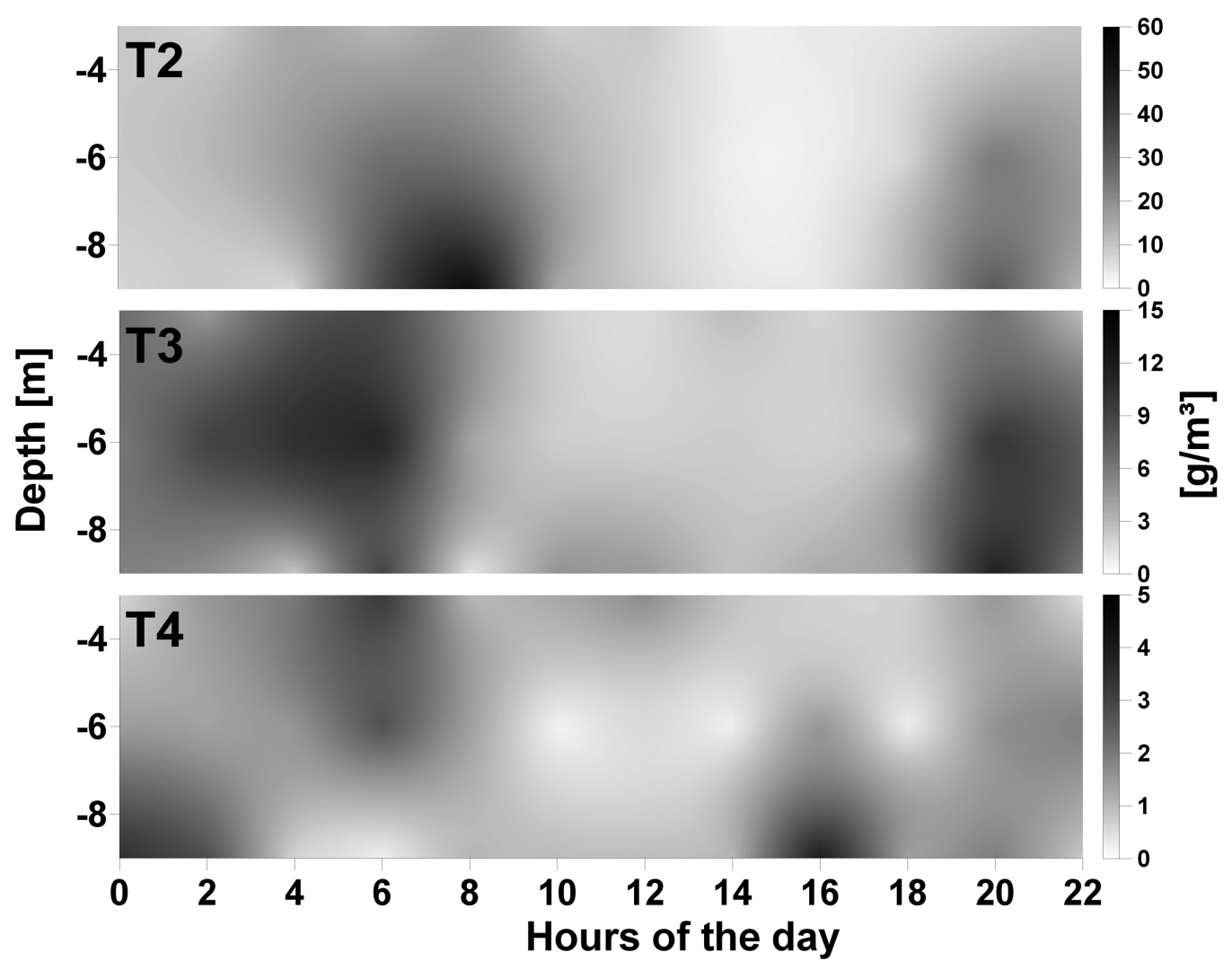

FIG. 4. - Isopleth representation of diel vertical distribution of fish recorded by transducers T2, T3 and T4. All July/November 1996 acoustic data combined. 

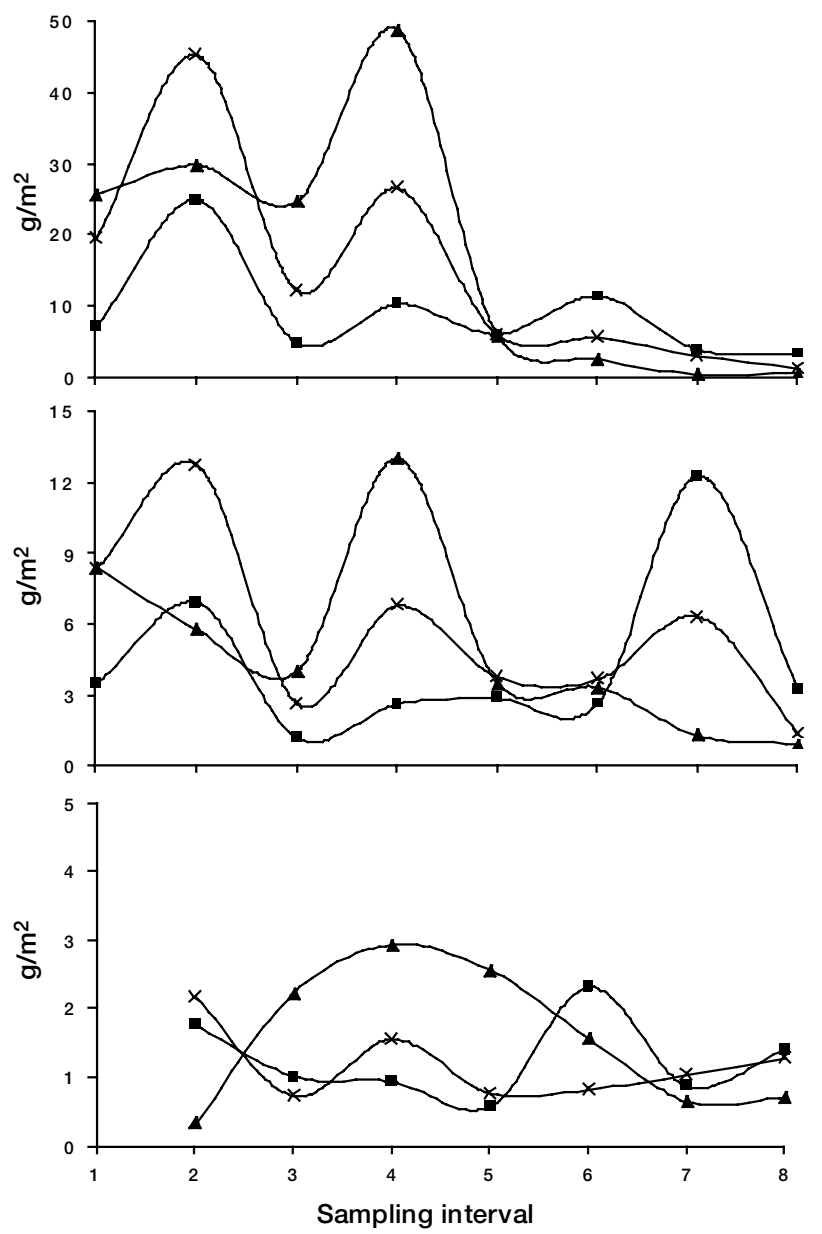

FIG. 5. - Geometric Means of fish biomass recorded by transducers T2, T3 and T4 in the overall sampling period at three different depth layers: surface (S), midwater (M) and bottom (B) layer.

layers and appeared anticipated, lasting from the night through to the very early morning. A slightly different behaviour was observed outside the protected area, which did not have a clear relationship to the light intensity. In fact, three biomass peaks were recorded: at night and early afternoon in the bottom layer and in the very early morning in the midwater and surface areas.

Throughout the sampling period, the biomass inside the reef followed a similar trend in the data recorded by transducers $\mathrm{T} 2$ and $\mathrm{T} 3$ (Fig. 5). However, the comparison conducted of the three different depth layers showed that fish biomass was not homogeneously distributed along the water column: the highest values were generally recorded in the middle and bottom layers until the end of August and the statistical differences were highly significant $(\mathrm{P}<0.001)$. A downward movement of uppermost and middle fish shoals was observed from July to the end of August when a sharp decrease occurred in the entire water column. Starting from the beginning of September, the fish biomass showed a rapid decline and the opposite situation was recorded with the minimum biomasses in the bottom layer and the maximum values at the surface. In further analysis, the Pearson correlation test revealed a negative relationship between the fish biomass and day factor in T2 and T3. This confirms that the fish biomass decreased as time passed throughout the study period.

In contrast, the fish biomass at $\mathrm{T} 4$ remained fairly uniform along the water column throughout the period and only negligible biomass variations in time were observed, with consistently low values at each layer (Fig. 5).

\section{DISCUSSION}

The multibeam sonar system proved to be an extremely efficient tool for observing the alteration incurred in the seabed of the reef area, and to depict the structure of the artificial reef by identifying the placement and orientation of each unit. In fact, it evidenced a general subsidence and a bathymetric unevenness of the seabed in the entire reef area, probably due to the erosion caused by currents and waves around the structures and the consequent collapse of several reef units. In addition, maps created with data from EM-3000 permitted more suitable sites for the placement of acoustic transducers to be selected; then, background imagery of the reef structures could be obtained and related to the fish distribution. Once it was decided where to place the acoustic equipment, the subsequent work demonstrated the ability of the fixed hydroacoustic technique to gather information on the distribution, daily behaviour, and biomass of the fish assemblage living inside and around the artificial reef.

The acoustic data revealed that the biomass and composition of the fish assemblage inside the reef were strictly related to the arrangement of the structures. Until the end of August, the area with a higher concentration of structures was characterised by higher densities and a predominance of benthic and nekto-benthic species, related to the greater availability of shelter, while a more homogeneous composition was recorded both in the spaces between the pyramids, and in the open sea. From the beginning of September, mobile pelagic species became dominant inside the reef, which was also confirmed by set net sampling (Fabi, unpublished data); this 
was due to the migration of the reef fish species from the coastal shallow waters to offshore, where the water temperature is about 10 to $12^{\circ} \mathrm{C}$ during the winter months (Fabi and Fiorentini, 1994).

According to Thorne et al. (1990), the diel behaviour of the fish assemblage living inside the reef showed minimum densities during the early afternoon, while the highest abundances were commonly observed late in the evening, at night, and in the early morning. A slightly different pattern was observed outside the reef, particularly in the afternoon. This diel variability of fish biomass might be connected either with fish horizontal migrations for foraging (Fabi et al., 2006) or with variability of fish acoustic response, expressed by TS-variability, due to environmental and biological factors (MacLennan et al., 1989, 1990; Orlowski, 2000). However, when more species are found in mixed pools, as on an artificial reef, the TS varies greatly and it may be convenient to summarise the analysis by quoting the regression TS-weight parameters, depending only on the mean size of the mixedspecies pool of fish (MacLennan and Simmonds, 1992). In the present study this value was determined based on the observable characteristics such as the species composition of the target population and the size of the individuals (Fabi and Sala, 2002).

Finally, the hydroacoustic records highlighted the area of influence of the artificial substrates of the surrounding habitat, and provided useful data for the management and planning of Adriatic artificial reefs. The values recorded by the off-reef transducer were generally lower than those collected by the inner ones, which shows that the effect of the reef on the fish assemblage was already reduced at about 80 $\mathrm{m}$ from the structures. This agrees with the results of other studies, which indicate that the local area of influence of an artificial reef may range from 5 to 50 $\mathrm{m}$, depending on the local environmental conditions and reef size (Continental Shelf Associates, 1982; Gerlotto et al., 1989; Fabi et al., 1999b).

The results of the present study demonstrated the suitability of hydroacoustic technology for providing continuous, reliable and detailed information on both the structure of an artificial reef and its fish assemblage that could not be collected with traditional sampling methods. On the other hand, given the difficulty of identifying some species from their sonar signal, a correct interpretation of the acoustic data requires in depth knowledge of the species composition of the reef community, which can only be obtained through visual or capture techniques. Using hydroacoustics associated with periodic visual or fishing verifications would give a complete picture of the reef system, which would lead to a better understanding of the relationships between fish and artificial substrates while facilitating significant savings in both the cost and working time.

\section{ACKNOWLEDGEMENTS}

This research was financially funded by the Italian Ministry of Merchant Marine - Fishery and Aquaculture Directorate. This support is gratefully acknowledged. Finally, we are also grateful to the editor and the reviewers for their comments, which we feel have improved our manuscript.

\section{REFERENCES}

Acosta, J., A. Muñoz, P. Herranz and C. Palomo. - 2001 Pockmarks in the Ibiza Channel and western end of the Balearic Promontory (western Mediterranean) revealed by multibeam mapping. Geo-Mar. Lett., 21: 123-130.

Augustin, J.M., R. Le Suave, X. Lurton, M. Voisset, S. Dugelay and C. Satra. - 1996. Contribution of the multibeam acoustic imagery to the exploration of the sea-bottom. Mar. Geophys. Res., 18(2-4): 459-486.

Beyer, A., R. Rathlau and H.W. Schenke. - 2005. Multibeam bathymetry of the Håkon Mosby Mud Volcano. Mar. Geophys. Res., 26: 61-75.

Bombace, G. - 1989. Les poissons recifaux. FAO Fish. Rep., 428: $84-85$.

Bombace, G., G. Fabi, L. Fiorentini and A. Spagnolo. - 1997. Assessment of the ichthyofauna of an artificial reef through visual census and trammel net: comparison between the two sampling techniques. In: L.E. Hawckins and S. Hutchinson (eds.), The Responses of marine organisms to their environments, pp. 291-305. Southampton Oceanography Center, University of Southampton (UK).

Bombace, G., G. Fabi and L. Fiorentini. - 2000. Artificial reefs in the Adriatic sea. In: A. Jensen, K. Collins and A. Lockwood (eds.), Artificial Reefs in European Seas, pp. 31-63. Kluwer Academic Publ., Dordrecht (Netherlands).

Bortone, S.A. and J.J. Kimmel. - 1991. Environmental assessment and monitoring of artificial habitats. In: W. Seaman and L.M. Sprague (eds.), Artificial habitats for marine and freshwaters fisheries, pp. 177-236. Academic Press, Inc., San Diego (California).

Bortone, S.A. and K.J. Mille. - 1999. Data needs for assessing marine reserves with an emphasis on estimating fish size in situ. Naturalista Siciliano (Suppl.): 13-31.

Buckley, R.M., and G.J. Hueckel - 1985. Biological processes and ecological development on an artificial reef in Puget Sound, Washington. Bull. Mar. Sci., 37: 50-69.

Cauwenberghe, C Van. - 1996. Multibeam echosounder technology: a time series analysis of sand movement. The Hydrogr. J., 81: 13-18.

Chakraborty, B., R. Mukhopadhyay, P. Jauhari, V. Mahale, K. Shashikumar and M. Rajesh. - 2006. Fine-scale analysis of shelf-slope physiography across the western continental margin of India. Geo-Mar. Lett., 26: 114-119.

Charbonnel, E., P. Francour and J.G. Harmelin. - 1997. Finfish populations assessment techniques on artificial reefs: a review in the European Union. In: A.C. Jensen (eds.), European 
Artificial Reef Research. Proceedings of the 1st EARRN Conference, Ancona (Italy), March 1996, pp. 261-277. Southampton Oceanography Center.

Clasper, P. - 1996. Aspects of QC in swathe bathymetry for pipeline route surveys. The Hydrogr. J., 79: 25-30.

Continental Shelf Associates. - 1982. Study of the effect of oil and gas activities on reef fish populations in Gulf of Mexico OCS area. OCS Report MMS 82-10. New Orleans, Louisiana. US Department of the Interior, Minerals Management Service, Gulf of Mexico Outer Continental Shelf Region. 210 pp.

Conway, K.W., J.V. Barrie and M. Krautter. - 2005. Geomorphology of unique reefs on the western Canadian shelf: sponge reefs mapped by multibeam bathymetry. Geo-Mar. Lett., 25: 205-213.

Demartini, E.E. D.A. Roberts and T.W. Anderson. - 1989. Contrasting patterns of fish density and abundance at an artificial rock reef and a cobble-bottom kelp forest. Bull. Mar. Sci., 44: 881-892.

Dziak, R.P., C.G. Fox, A.M. Bobbit and C. Goldfinger. - 2001. Bathymetric map of the Gorda Plate: structural and geomorphological processes inferred from multibeam surveys. Mar. Geophys. Res., 22(4): 235-250.

Fabi, G. and L. Fiorentini. - 1994. Comparison between an artificial reef and a control site in the Adriatic Sea: analysis of four years of monitoring. Bull. Mar. Sci., 55(2-3): 538-558.

Fabi, G., F. Grati, F. Luccarini and M. Panfili. - 1999a. Indicazioni per la gestione razionale di una barriera artificiale: studio dell'evoluzione del popolamento necto-bentonico. Biol. Mar. Medit., 6(1): 81-89.

Fabi, G., F. Luccarini, M. Panfili and A. Spagnolo. - 1999b. Valutazione dell'efficacia delle strutture artificiali nei mari italiani: studio del funzionamento del sistema barriere artificiali attraverso le reti trofiche. Report to the Ministry for Agricultural Politics, Fishery and Aquaculture Directorate.

Fabi, G., Sala, A. - 2002. An assessment of biomass and diel activity of fish at an artificial reef (Adriatic sea) using stationary hydroacoustic technique. ICES J. Mar. Sci., 59(2): 411-420.

Fabi G., S. Manoukian, A. Spagnolo. - 2006. Feeding behaviour of three common fishes at an artificial reef in the northern Adriatic sea. Bull. Mar. Sci., 78(1): 39-56.

Gerlotto, F., C. Bercy and B. Bordeau. - 1989. Echo integration survey around offshore oil extraction platforms off Cameroon: observations of the repulsive effect on fish of some artificially emitted sounds. Proceedings of the Institute of Acoustics, 19: 79-88.

Grigg, R.W., E.E. Grossman, S.A. Earle, S.R. Gittings, D. Lott and J. McDonough. - 2002. Drowned reefs and antecedent karst topography, Au'au Channel, S.E. Hawaiian Islands. Coral Reefs, 21: 73-82.

Hansen, B.W. and R. Simonis. - 1994. Deep water pipe route mapping. Proc. Hydro '94, Sept. - 1994, pp. 1-18. The Hydrogr. Soc., Aberdeen, Scotland (UK).

Harmelin-Vivien, M.L., J.G. Harmelin, C. Chauvet, C. Duval, R. Galzin, P. Lejeune, G. Barnabé, F. Blanc, R. Chevalier, J. Duclerc, and G. Lasserre. - 1985. Evaluation visuelle des peuplements et populations de poissons: Méthodes et problèmes. Revue d'Ecologie (Terre Vie), 40: 467-539.

Hovland, M., S. Vasshus, A. Indreeide, L. Austdal and Ø. Nilsen. 2002. Mapping and imaging deep-sea coral reefs off Norway, 1982-2000. Hydrobiologia, 471: 13-17.

Kammerer, E., J. Clarke, E. Hughes, J. Locat, N. Douchet and A. Godin. - 1998. Monitoring temporal changes in seabed morphology and composition using multibeam sonars; a case study of the 1996 Saguenary river floods. Proc. Can. Hydrogr. Conf. 10-12 March 1998, pp. 450-461. Canadian Hydrographic Association, Vancouver, British Columbia (Canada).

Knaapen, M.A.F., C.N. van Bergen Henegouw and Y.Y. Hu. 2005. Quantifying bedform migration using multi-beam sonar. Geo-Mar. Lett., 25: 306-314.

Lawrence, M.J. and C.R. Bates. - 2001. Acoustic ground discrimination techniques for submerged archaeological site investigations. Mar. Tech. Soc. J., 35(4): 65-73.

MacLennan, D.N., C.E. Hollingworth and F. Armstrong. - 1989. Target Strength and the tilt angle distribution of caged fish. Proc. Inst. Acoustics, 11(3): 11-20.

MacLennan, D.N., A.E. Magurran, T.J. Pitcher and C.E. Hollingworth. - 1990. Behavioural determinants of fish Target
Strength. Rapp. p.v. CIESM, 189: 245-253.

MacLennan, D.N. and E.J. Simmonds. - 1992. Fish. Acoustics. Chapman and Hall, London. 325 pp.

Mayer, L.A. and B. Kenneth. - 2001. Shallow Water Survey 2001: papers based on selected presentations from the Second International Conference on High Resolution Surveys in Shallow Water. Mar. Tech. Soc. J., 35(4): 3-4

Mayer, L.A., B.R. Calder, J. Schmidt and C. Malzone. - 2003. Providing the third dimension: high resolution multibeam sonar as a tool for archaeological investigations - an example from the D-Day beaches of Normandy. U.S. Hydrogr. Conf., Biloxi MS, 2003.

Mayer, L.A. - 2006. Frontiers in seafloor mapping and visualization. Mar. Geophys. Res., 27: 7-17.

Miller, R.J. and W. Hunte. - 1987. Effective area fished by antillean fish traps. Bull. Mar. Sci., 40: 484-493.

Mitchell, N.C. - 1996. Processing and analysis of Simrad multibeam sonar data. Mar. Geophys. Res., 18(6): 729-739.

Mosher, D.C. and R.E. Thomson. - 2002. The Foreslope Hills: large-scale, fine-grained sediment waves in the Strait of Georgia, British Columbia. Mar. Geol., 192: 275-295.

Nakamura, M. - 1985. Evolution of artificial fishing reef concept in Japan. Bull. Mar. Sci., 37(1): 271-278.

Okamoto, M. - 1991. - Methods of estimating fish abundance around reefs. In: M. Nakamura, R.S. Grove, and C.J. Sonu (eds.), Japan-U.S. Symposium on Artificial Habitats for Fisheries Proceedings, pp. 105-114. Southern California Edison Company, Rosemead (California).

Orlowski, A. - 2000. Diel dynamics of acoustic measurements of Baltic fish. ICES J. Mar. Sci., 57: 1196-1203.

Paton, M., L. Mayer and C. Ware. - 1997. Interactive 3D tools for pipeline route planning. Proc. Oceans'97, October 1997, pp. 1216-1221. MTS/IEEE, Halifax, NS, Canada.

Popper, L.J., M.L. DiGiacomo-Cohen, S.M. Smith, H.F. Stewart and N.A. Forfinski. - 2006. Seafloor character and sedimentary processes in eastern Long Island Sound and western Block Island Sound. Geo-Mar. Lett., 26: 59-68.

Roberts, J.M., C.J. Brown, D. Long and C.R. Bates. - 2005. Acoustic mapping using a multibeam echosounder reveals cold-water coral reefs and surrounding habitats. Coral Reefs, 24: 654-669.

Ross, S.L., D.M. Boore, M.A. Fisher, A.D. Frankel, E.L. Geist, K.W. Hudnut, R.E. Kayen, H.J. Lee, W.R. Normark and F.L. Wong. - 2004. Comments on potential geologic and seismic affecting Coastal Ventura County, California. USGS Open-File Report 2001-1286.

Shaw, J., R.C. Courtney and J.R. Currie. - 1997. Marine geology of St. George's Bay, Newfoundland, as interpreted from multibeam bathymetry and back-scatter data. Geo-Mar. Lett., 17: 188-194.

Shyue, S.-W. - 1998. Preliminary study on the distribution of artificial reefs by using multibeam echo sounder. Proc. Oceans' 98 , October 1998, pp. 1144-1148. IEEE/OES, Nice, France.

Shyue, S-w and K-c Yang. - 2002. Investigating terrain changes around artificial reefs by using a multi-beam echosounder. ICES J. Mar. Sci., 59(S): 338-342.

Singh, H., J. Adams, D. Mindell, and B. Foley. - 2000. Imaging Underwater for Archaeology. J. Field Archaeology, 27(3): 319-328.

SIMRAD. - 1995. Simrad EY500 Portable Scientific Echo Sounder. Operator Manual. SIMRAD, Norway.

Snedecor, G.W. and W.G. Cochran. - 1967. Statistical methods. Iowa State University Press, Ames. 593 pp.

Somerton, D.A., B.S. Kihkaway and C.D. Wilson. - 1988. Hook times to measure the capture time of individual fish. Mar. Fish. Rev., 50: 1-5.

Soldal, A.V., I. Svellingen, T. Jørgensen and S. Løkkeborg. - 2002. Rigs-to-reefs in the North Sea: hydroacoustic quantification of fish in the vicinity of a "semi-cold" platform. ICES J. Mar. Sci., 59(S): 281-287.

Stanley, D.R. and C.A. Wilson. - 1998. Spatial variation in fish density at three petroleum platforms as measured with dualbeam hydroacoustics. Gulf of Mexico Science, 1: 73-82.

Stanley, D.R., C.A. Wilson and C. Cain. - 1994. Hydroacustic assessment of abundance and behaviour of fishes associated with an oil and gas platform off the Louisiana coast. Bull. Mar. Sci., 55: 1353. 
$364 \cdot$ A. SALA et al.

Thorne, R.E., J.B. Hedgepeth and J.A. Campos. - 1989. Hydroacoustic observations of fish abundance and behaviour around an artificial reef in Costa Rica. Bull. Mar. Sci., 44(2): 1058-1064.

Thorne, R.E., J.B. Hedgepeth and J.A. Campos. - 1990. The use of stationary hydroacoustic transducers to study diel and tidal influences of fish behaviour. Rapp.p.v. CIESM, 189: 167-175.

Thorne, R.E. - 1994. Hydroacustic remote sensing for artificial habitat. Bull. Mar. Sci., 55: 897-901.

Todd, B.J., G.B. Fader, R.C. Courtney and R.A. Pickrill. - 1999.
Quaternary geology and surficial sediment processes, Browns Bank, Scotian Shelf, based on multibeam bathymetry. Mar. Geol., 162: 165-214.

Wickam, D.A. and G.M. Russel. - 1974. An evaluation of midwater artificial structures for attracting coastal pelagic fishes. Fish. Bull., 72: 181-191.

Scient. ed.: D. Vaqué.

Received February 27, 2006. Accepted February 6, 2007.

Published online May 24, 2007. 